\title{
ANALYSIS OF THE PRACTICES OF SUPERVISION AT ELEMENTARY SCHOOL LEVEL IN PUNJAB
}

\author{
Bakht Jamal \\ Research Scholar, \\ Department of Education, International Islamic University, \\ Islamabad, Pakistan \\ Email: bakht.phdedu155@iiu.edu.pk

\section{Syed Asad Abbas Rizvi} \\ Associate Professor, \\ Department of Education, Begum Nusrat Bhutto Women University Sukkur, \\ Sindh, Pakistan \\ Email: asad.rizvi@bnbwu.edu.pk

\section{Muhammad Munir kayani} \\ Associate Professor, \\ Department of Education, International Islamic University, \\ Islamabad, Pakistan \\ Email: drmm_kayani@iiu.edu.pk
}

\begin{abstract}
Supervision is one of the important factors for school improvement and ensuring quality education. It makes the teaching-learning environment effective and helps us to achieve the educational objectives. The current research study was designed to explore analyze the practices of supervision at elementary schools' level in Punjab. The population of the study was 166 elementary schools and 64 supervisors. The sample respondents of the study were 50 head teachers and 16 supervisors of elementary schools' public sector in the District. The researcher adopted a convenience sampling technique for the collection of data. The tool for the collection of data were two self-developed questionnaires on a five-point rating scale, one for head teachers and the second one for supervisors having forty-two (42) statements with eleven aspects regarding (1) objectives, (2) cooperation, (3) cleanliness, (4) quality of education, (5) motivation, (6) facilities, (7) attendance, (8) budget, (9) feedback, (10) problems and (11) universal primary education. The validity of the research instrument was properly ensured through experts' opinions and pilot testing. The reliability of the instruments was ensured by applying the Cronbach Alpha. The value of the reliability for supervisors was found 0.939 and the reliability value for the head teachers was measured at 0.932. The data collected from respondents were
\end{abstract}


subsequently organized properly. The collected data was accurately analyzed, tabulated, presented and interpreted. Descriptive statistics were applied and data was

presented in the mean score, frequency and standard deviation and interpreted accordingly. The data was presented in the form of tables. It was concluded that the supervisors are discharging their professional responsibilities with the spirit to promote quality education, promote a healthy and child-friendly environment in schools and head teacher are keen on conveying the instructions from the supervisors to the teachers.

\section{KEYWORDS}

Supervision, Universal Primary Education, Feedback, School Environment, Quality Education

\section{INTRODUCTION}

Supervision is a Latin word that means over and sees. It is also a process in which the supervisor identifies faults and solves them. Supervision is a professional technique in which knowledge and competencies aimed at increasing practice or guidance through a mutual interpersonal process. It is composed of observation, assessment, and feedback. The main purpose of the supervisee is to gain self-assessment and also gaining knowledge and skills (Ahmad, 2013). Tesema (2014) described that the Supervision of school-oriented generally is the improvement of the teaching process and the situation that affects this process. It is a multifunction function process that improves education by mutual working and later involving students. Supervision is taken as the procedure in which supervisors inspected schools for the purpose to improve the quality of teaching and administration. Hence, effective guidance and facilitation are necessary to improve teaching as well as administration. When we view supervision in the school context, it is the process of observation, make decisions and discuss it with the teachers and head teachers for the improvement of the educational process. Educational supervision is not a one-way process but it demands joint efforts, mutual understanding and constructive activities among different stakeholder such as teachers, head teachers and supervisors that that smooth the way to achieve the educational objective effectively. So it is the responsibility of them to promote these values based on mutual understanding and cooperation and it will help them out to achieve the desired goals effectively and efficiently.

Creaner (2013) explained that supervision serves some related functions. It first and foremost exists for the professional competencies of the supervisee. Supervision is a source of developing the relationship in which the supervisor guides and leads the teachers to achieve the targets. If we focus on quality education, students' learning can be highly improved. So supervision should be our preference to raise the quality of education. Supervisors should focus on improving classroom instructions to develop 
teachers' competencies in the teaching-learning process. Children are motivated by their parents and teachers to accomplish determined standards. It is time required activity for achieving the standards. Supervision is a necessary part of schools and without these activities; it will be a question mark to monitor the schools effectively. By supervision, Supervision in schools is an important process to support the teachers about the new dynamics of teaching. It is to make accessible for teachers' instructional materials which are useful for successful teaching and learning in education.

Adu (2014) defined supervision as the systematic mechanism of the application of the principles of supervision to achieve the educational objectives effectively and solve the problems by giving professional support and guidance. The main purpose of educational supervision is to achieve the educational objective, students learning outcomes and create a supportive environment for teaching and learning. It also manages educational activities and motivates the stakeholders for the end purpose which is the imparting of quality education. Olorode \& Aleyemo (2012a) stated that educational Supervision is an area to manage education. Supervision is a process to supervise all education process, linking between workload and increasing the potential of working people. It provides to lead the educational process and guide the educational leaders. This service guides educational leadership to work sufficiently. Olorode \& Aleyemo (2012b), opined that educational supervision is the area of educational management and it manages the educational operation with coordination and develops working relationships among all stakeholders involved in teachinglearning activities. The supervisors provide professional support and guidance and convey the directions of the government to meet desired educational objectives and meet the targets. It provides opportunities to the supervisors to implement the government policies and monitor the schools progress. Educational supervision is helpful to promote quality education and meet the students' needs related to curricular and co-curricular activities. Supervision is the mechanism that smooth the way to implement the educational program in an effective way to achieve the targets of quality education. The process of supervision enables the teachers to enhance their competencies, professional skills and adopt innovative teaching methods to achieve the educational targets. Through supervision, teachers and head teachers take initiatives based on mutual understanding, cooperation and joint efforts that makes the school environment supportive to teaching learning and in this way the supervisors and school managers achieve the desired goals.

\section{LITERATURE REVIEW}

Bhelol (2011) mentioned that supervision is the activity of improving the administration as well as educational activities. The main purpose of supervision is to facilitate and guide the teachers to develop professional skills. It is also viewed as a process that is positive, forward-looking and the primary focus is to help the individual 
to progress. It is a general notion that schools cannot be developed without its teachers' professional development and the quality of teacher education is based on the provision of proper support from supervisors. Al Nazer (2013) stated that educational supervision is an important element to improve education overall and improvement in the pedagogy of teachers made this element very effective. Behaviour change is possible through inculcating teaching knowledge, values and skills. According to Carrón \& Grauwe (1997), Supervision is a comprehensive procedure as it covers many aspects like inspecting, controlling, evaluating, advising, assisting and supporting school heads and teachers. According to Ahmed (2013) supervision is an effective tool that we use to improve the education system. It provides us with information that to what extent we achieved the determined standard. It also provides us with the strengths and weaknesses of some of the education systems.

Memduhoglu (2007)) argued that historically the function of supervision authority but in the present era it is considered as development in professional skills. In the present era, visits are done by the supervisor to implement the government rules as per its spirit. So this process develops leadership qualities in teachers. Donkoh (2014) described that with cooperation, teachers can move ahead positively to achieve the determined goals. So it helps us to solve the problems with cooperation and understanding approach. The observation reflected the fact that supervisors are facing many difficulties and problems during supervising and it may decrease their efficacy and their definitive impact on what is going on in the schools and the classrooms. Some of these problems are financial, social, departmental and educational. Vazir (2008) believes that supervision is also the process of examining and evaluating to collect information and improving the teaching and learning environment. The main and important aim of this activity is to bring improvement and development in teaching as well as the administration process. The supervisor also guides the teachers and facilitates them in administrative problems. The most professional and trained administrators not only achieve the educational goals but also lead the teachers positively.

Dwamena (2014) explains that teachers can gain quality in their subject area and they can transform their experiences by applying collaboration technique. Through collaboration, teachers can solve the problems in the educational process and thus make the supervision a cooperative problem-solving approach. Supervisors are facing different problems in performing their duties which reduce the performance as they want in schools and from the teacher in classrooms. Oye (2009) argued that the success of educational objectives is possible by determining educational trends of teachers and linkage of professional skills and effective supervision. Supervisors can motivate them positively and effectively to achieve their educational goals. 
Ahmad (2013) explained that the process of supervision in Pakistan is a link with inspection and not supportive as it demands. The supervisors behave authoritatively and discourage teachers. Therefore, professional skills and teaching effectiveness remain poor. As a result, mistrust and discouragement develop and teacher performance decrease with time. Supervision demands to improve the knowledge, values, skills of teaching and also develop a supportive teaching-learning environment in the schools. Govinda (1999) said a supervisor requires many characteristics to perform smoothly. These characteristics include; confidence, sympathetic approach, sincere approach, professional commitment, mission and vision, continuity in work, partnership and supportive approach with the teacher, effective communication skills and role model, leadership and innovative technique in performing supervision.

According to Jamila (2012), the quality of education is linked with the quality of supervision and essential facilities in schools. The favorable and supportive environment makes it smooth and easy to perform and make the teaching-learning process effective with the help of proper supportive supervision. On the other side, poor and authoritative supervision create problems and discourage teachers which are responsible to deliver effective teaching and make the learning environment easy for their students. Elementary education depends on the resources and facilities which are present in schools. These resources and facilities include; teachers training, provisions of books, teaching aids and an effective supervision system to achieve the educational goals effectively and efficiently. Supervision helps teachers to understand the responsibilities and implement them in true spirit (National education policy, 2009).

Fong (1994) stated that the development of supervising practices made the school and the educational supervision a nucleus of the development process. The supervisor positive role in developing the supervision process develop the school whole environment and education management very effective. Many activities recommended by elementary supervisors include; conferences and meetings with local groups of teachers and superintendents, with members of other divisions in departments of education, and individual conferences with teachers or administrators who visit the department offices. Gordon (1994) identified the practices of supervision which play an important role in ensuring quality education and achieving the students learning outcomes effectively. The practices which are common in supervision as coordinating the supervisory activities, planning for supervision, motivating, leading, managing, communicating and resolving supervisory problems. Ekyaw (2014a) Supervision also mentioned some practices of supervision such as assessment of the performance of the schools, provision of professional support such as introducing instructional strategies, learning materials, improvement in classroom teaching-learning environment, conducting meetings, workshops and training sessions for the overall improvement of the school environment and to achieve the students learning outcomes effectively. 
Professional guidance and support, mentoring and monitoring of the progress of the teaching-learning process, ensuring the provision of physical resources, delivery of free textbooks to the students, keeping records of the managerial work and taking initiatives for the achievement of the universal primary education targets are the practices that supervisors do effectively and efficiently.

Ekyaw (2014b) stated that quality learning in classrooms is linked with effective and supportive supervision. So supportive and conducive environment for learning is very necessary and it is possible through supportive supervision. The supervisors can identify the professional needs of teachers and give recommendations to the government for conduction. Razaq (2012) argue that due to lack of facilities and poor management resulted in the poor quality of the teaching-learning process and as a result, the educational goals remain unachieved. There are so many schools deprived of basic physical and learning facilities and it resulted in poor quality education. Ellis (2007) explored that supervisors also facing so many problems. These problems include; transportation especially female supervisors, lack of funds and accommodation. The other problems are such as insufficiently qualified supervisors who are lacking in pedagogical skills, professional approaches and lack in supervisory training. The behaviour of the supervisors in Pakistan is also under criticism. The harassment of teachers and students is one of the areas of complaint which needs to be addressed. The other problems are the non-availability of vehicles to supervisors especially female supervisors in rural areas, limited time supervision, poor planning for supervision, no implementation of supervisory reports, no provision of feedback about supervision reports, corruption in supervision, teacher are reluctant in accepting supervision, overload and extra work except supervision and no interest of supervisors in remote and rural areas are the basic problems of supervision which needs to be addressed on a priority basis.

Rehman et al (2014) suggested many solutions to the problems that supervisors are facing during supervision practices. The most important thing is to increase the number of supervisors and recruit them according to the modern trends, equipped them with professional skills and competencies to produce the desired results and ensure quality education. The present scenario reflects the fact that the majority of the supervisors are not equipped with professional skills and techniques and they are under criticism due to their failure in producing desired results. The other initiative that is necessary is professional training for the overall school improvement in curricular and co-curricular activities. Supervisors must be well equipped with professional skills, modern teaching methodologies and techniques to impart the knowledge and skills according to the needs of society and students. It is also necessary for them to participate in professional training and impart it with the teachers at the school level. The training initiative will promote the teacher competencies and professional skills and they will feel 
comfortable to meet the educational objectives and impart the knowledge and skills according to the determined standards.

Wilcox (2000) stated that motivation is also necessary to produce the desired results of supervision. Supervisors are the most neglected sector of the education workforce. The need of the time is that the supervisors should be highly motivated and pay the salaries timely to the teachers. The teachers' accommodation is also an incentive to teachers that will bring positive results in performance and delivering their professional duties. Provisions of funds are also essential for the purchasing of physical resources and developing a healthy and child-friendly environment in the schools. The element of cooperation plays a role to promote a healthy environment in the schools and gain results through mutual understanding and joined efforts. There is a need for cooperation among all the stakeholder such as teacher, head teacher and supervisors to promote a healthy and supportive environment in the schools and meet the assigned targets related to curricular and co-curricular activities. For the achievement of desired educational goals, it is necessary to involve the teachers and head teachers in the decision making and initiative process as they both are the backbone of the supervision mechanism and through their joint efforts the educational goals can be achieved smoothly.

Drysdale (2011) argue that the feedback and follow up visits in terms of support and guidance from supervisors to the students, teachers and head teachers can develop a supportive environment for learning. There is a need for follow up for the purpose to provide professional guidance and support to the teacher in improving their professional competencies. The discussion with all stakeholder will also promote a supportive environment for learning. Provision of office accommodation and other resources for supervision is also the one important solution to solve the problem the supervisors are facing during the practices of supervision. The need of the time is that the provision of ample physical resources and funds for the purchasing of physical and learning resources. Through the resources, the teachers and head teachers may smoothly discharge their duties and responsibilities. Provision of vehicles and facilities for supervision will solve the problems and smooth the way in performing the duties and responsibilities of supervision. Effective supervision requires sufficient fund to purchase and maintain the vehicles that will convey the supervisors to and from schools. There should be sufficient provision of the fund and on-time release of the fund to the supervisors by the government to encourage them towards effective discharge of their duties. It has been observed that in most areas of Pakistan, vehicles for supervision exercise are not available while most of the available ones are in bad condition thus making it impossible for supervisors to carry out regular supervision.

Ali (1998) stated that timely writing of supervision reports will help out to actively 
involved all the stakeholders to participate and take initiatives for quality education. There is a need for reports of supervision to be prepared in available to parents and other stakeholders such as the board of governors, School committees and all education officers. The one solution to the problems of the supervisors is the role of managerial work. The supervisors should play an active role in performing this role such as paying the salaries to the teachers' time and should work on the in-service promotions of the teachers to gain the desired results. Promotions are delayed without justification. In a situation where teachers are frustrated and fail to show interest in supervision, the job of a supervisor is made more difficult for the achievement of the objectives of educational supervision.

Supervision is the process that makes the teaching process effective and guides the teachers and students to ensure quality education. Through supervisory practices, the supervisors conduct professional training sessions and meetings to convey the instruction of the higher authorities and ensure to implement it. The supervisor not only communicates to head teachers and teachers but also develop personal relations to implement the government policies at the grassroots level. The supervisors enable the subordinate to perform according to the directions of their seniors and produce the best possible results for their students learning according to the national curriculum objectives and students learning outcomes. Supervisors discharge their responsibilities according to the supervisory roles and also develop relations with the community members, honourable of the society, school council and elected members to ensure the implementation of the government rules and laws with the support of the society. There is no doubt that community support ensures the achievement of the desired results. The supervisors currently involving all stakeholder such as students, teachers, head teachers, school council, respectable of the community elected members, retired teachers and social activist to achieve the assigned targets of the supervision and ensure the delivery of quality education with spirit. Through the involvement of the community, it is possible to get the desired objectives by joint efforts, cooperation, understanding, motivation and applying professional skills and approach for the achievement of quality education which is the main purpose of the supervision. The current study will identify the supervisory practices of the supervisors and will explore the extent of these practices at the level of the District in Punjab.

\section{RESEARCH OBJECTIVES}

1. To identify the various supervisory practices.

2. To explore the extent to which supervisors discharge their responsibilities.

\section{RESEARCH QUESTIONS}

1. What are the practices of supervision?

2. What professional support supervisors provide to teachers to improve the whole 
performance of schools?

\section{RESEARCH METHODOLOGY}

A descriptive research design was used in the study to explore the practices of supervision and the responsibilities of the supervisors at elementary schools' level in Punjab. The population of the study was 166 elementary schools and 64 supervisors. The sample respondents of the study were 50 head teachers and 16 supervisors of elementary schools. The researcher developed two questionnaires as an instrument on a five-point rating scale, one for head teachers and the second one for supervisors which was based on forty-two (42) statements with eleven aspects regarding (1) objectives, (2) cooperation, (3) cleanliness, (4) quality of education, (5) motivation, (6) facilities, (7) attendance, (8) budget, (9) feedback, (10) problems and (11) universal primary education. The teachers were asked to give their response on (1) never, (2) rarely, (3) sometimes, (4) often and (5) always. For the validation process, both the questionnaires were validated through experts' opinions. The questionnaires were refined in the light of expert opinions and instructions two times. The researcher adopted a convenience sampling technique for the collection of data. The validity of both the questionnaires were ensured through experts' opinions. Both the questionnaires were refined two times in the light of feedback received from the experts. The pilot testing was also conducted and the researcher personally delivered the instruments to 10 elementary head teachers and 5 supervisors who were not the genuine part of the study. Cronbach Alpha was used for the reliability of the instruments. The value of the reliability was found 0.939 for supervisors. The reliability value of the instrument for the head teachers was found 0.932 . The final data were collected personally by the researcher. Data were analyzed by applying descriptive statistics such as mean score, frequency and standard deviation. The collected data were accurately interpreted and presented in the form of tables. The research concluded that the supervisors discharging their responsibilities with the spirit to improve the quality of education in elementary schools in Punjab. The head teachers are seriously taking actions on the instructions of supervisors and also conveyed the instructions to their subordinate teachers. The research reflected that head teachers are performing to eradicate the problems of supervision and supporting the supervisors in performing supervisory responsibilities.

\section{DATA ANALYSIS \& INTERPRETATION}

Table 1: Showing Mean score and standard deviation on all aspects of supervisors

\begin{tabular}{lccc}
\hline S. No Indicators & $\begin{array}{c}\text { Mean gained } \\
\text { Score }\end{array}$ & N & $\begin{array}{c}\text { Std. } \\
\text { Deviation }\end{array}$ \\
\hline 1. Educational objectives & 12.63 & 16 & 2.879 \\
2. Cooperation with teachers & 21.83 & 16 & 4.057 \\
\hline
\end{tabular}




\begin{tabular}{llll}
\hline 3. Cleanliness of schools & 12.63 & 16 & 2.445 \\
4. Quality education for students & 29.44 & 16 & 6.695 \\
5. Motivation of staff & 8.75 & 16 & 1.27 \\
6. Provision and functioning of facilities & 8.94 & 16 & 1.335 \\
7. Attendance of students & 12.76 & 16 & 2.762 \\
8. Budget utilization and maintenance record & 13.57 & 16 & 2.139 \\
9. Observations on feedback & 12.31 & 16 & 1.954 \\
10. Problems of supervision and head teachers & 19.32 & 16 & 6.329 \\
11. Universal primary and secondary education & 20.25 & 16 & 5.274 \\
Total mean and standard deviation & 174.34 & 16 & 37.134 \\
\hline
\end{tabular}

Table 1 shows that the supervisors are working efficiently for the improvement of educational activities in elementary schools and eradicating supervisory hurdles. It was found on the educational objectives (Mean=12.63, $\mathrm{SD}=2.879$ ); Cooperation with teachers $($ Mean=21.86, $\mathrm{SD}=4.057)$; cleanliness of schools(Mean=12.63, $\mathrm{SD}=2.445)$; quality education for students (Mean=29.44, $\mathrm{SD}=6.695)$; motivation of staff (Mean=8.75, $\mathrm{SD}=1.271$ ); provision and functioning of facilities (Mean=8.94, $\mathrm{SD}=1.335)$; attendance of students(Mean=12.76, $\mathrm{SD}=2.762)$; total mean on budget and maintenance of record (Mean=13.57, $\mathrm{SD}=2.139)$; observation on feedback (Mean=12.31,SD=1.954); problems of supervision and Head teachers (Mean=19.32, $\mathrm{SD}=6.329)$; universal primary and secondary education (Mean=20.25, $\mathrm{SD}=5.274$ ).

Table 2: Showing the mean score and standard deviation on all aspects of Head teachers

\begin{tabular}{lccc}
\hline S. No Indicators & Mean Score & N & Std. Deviation \\
\hline 1. Educational objectives & 11.5 & 50 & 3.271 \\
2. Cooperation with head teachers & 19.4 & 50 & 5.594 \\
3. Cleanliness of schools & 10.06 & 50 & 3.715 \\
4. Quality education for students & 27.5 & 50 & 7.714 \\
5. Motivation of staff & 7.40 & 50 & 2.128 \\
6. Provision and functioning of facilities & 7.88 & 50 & 2.110 \\
7. Attendance of students & 11.20 & 50 & 3.623 \\
8. Budget utilization and maintenance record & 12.68 & 50 & 3.184 \\
9. Observation on feedback & 11.56 & 50 & 2.088 \\
10. Problems of supervision and head teachers & 23.68 & 50 & 6.711 \\
11. Universal primary and secondary education & 18.74 & 50 & 5.921 \\
Total mean score and standard deviation & 162.14 & 50 & 46.114 \\
\hline
\end{tabular}

Table 2 indicates that the Head teachers mean gained score and standard deviation score playing important role in supervisory practices and facilitating educational activities at the elementary school of Punjab. The mean score on educational objectives 
of Head teachers (Mean=11.5, $\mathrm{SD}=3.271$ ); cooperation with teachers (Mean=19.4, $\mathrm{SD}=5.594)$; cleanliness of schools (Mean=10.06, $\mathrm{SD}=3.715$ ); quality of education for students (Mean=27.5, SD=7.714); motivation of staff (Mean= 7.40, $\mathrm{SD}=2.128$ ); provision and functioning of facilities (Mean=7.88, $\mathrm{SD}=2.110$ ); attendance of students (Mean=11.20, $\mathrm{SD}=3.623$ ); budget and maintenance of record (Mean=12.68, $\mathrm{SD}=3.184)$; observation on feedback (Mean $=11.56, \mathrm{SD}=2.088$ ); problems and supervision of head teachers (Mean=23.68, $\mathrm{SD}=6.711$ ); universal primary and secondary education (Mean=18.74, $\mathrm{SD}=5.921$ ).

\section{DISCUSSION}

The key concern of this investigation was about the problems and practices of supervision at elementary schools in Punjab: And the analysis, the objectives of this study were: (a) to identify the various supervisory practices. (b) To explore the extent to which supervisors discharge their responsibilities.

The research explains that the supervisor is discharging their duties and responsibilities effectively and efficiently in eradicating the supervision related problems and facilitating teachers and head teachers to improve the overall environment for educational activities. The supervisors also have taken actions on the spot to remove the hurdles and support the educational activities and quality of education. The supervisors are taking an interest to achieve the educational objectives and they observe the classroom teaching-learning environment on the spot and give suggestions for the improvement of teaching methodologies of the teachers by giving feedback and professional support. The supervisors are shown their cooperative behaviour with teachers as well as with head teachers. Supervisors are taking a keen interest in a childfriendly environment and school cleanliness by giving direction and professional support in making the healthy environment of the schools. The supervisors are involved to ensure the delivery of quality education, motivate the students, teachers and head teachers, ensuring to provide the classroom related physical facilities, giving directions and support to raise the attendance ratio of the students by involving self, teachers and head teachers to get the cooperation of the concerned community. The supervisors are also giving their guidance in utilizing the budget for the welfare of the students and whole school improvement. The supervisors' launch campaigns to achieve the targets of universal primary education by involving the community, teachers and head teachers, conducting meetings, involving school council and honourable members of the community.

The research also reflected that head teachers of elementary schools are also pursuing the instructions of supervisors and they also conveyed the supervisory instructions to their subordinate teachers to uplift the quality of education. The head teachers are taking a keen interest in achieving the students learning objectives and providing 
support to teachers. The head teachers took the initiatives to get the cooperation of teachers and students to make the school environment clean and green by adopting a democratic approach, taking their suggestions and involved them to contribute in this regard. The head teachers also took the initiatives to functionalize the physical resources for the teaching and learning process to make the students learning effective and permanent, allocated the budget for the functioning of the resources. Head teachers are involved in observing the classroom teaching-learning process and promote cooperation and communications with the community to achieve the targets of universal primary education. In most of the school, the teachers and head teachers achieved this target effectively.

\section{CONCLUSION}

The key concern of the research was to identify various key supervisory practices at elementary schools in Punjab. The scholar identified various supervision practices and concluded based on the investigation that most supervisors and head teachers of elementary schools are performing them effectively and efficiently.

The research also concluded that the supervisors discharging their responsibilities with the spirit to improve the quality of education in elementary schools in Punjab. The research concluded that most supervisors and head teachers are performing according to their roadmap of responsibilities such as observing classroom teaching-learning process to observe the process of achieving students learning outcomes. The supervisors are also taking initiatives to develop the cooperation among students, teachers and heard teachers, ensuring the cleanliness of the school, motivate students, teachers and head teachers to make the school environment child friendly and healthy for learning, factionalized the physical resources of the school and launched awareness initiatives such as conducting meetings with teachers, head teachers, community members and respectable of the community to achieve the targets of universal primary education.

The opinions of the head teacher reflected the fact that they are seriously taking actions on the instructions of supervisors and also conveyed the instructions to their subordinate teachers. The research reflected that head teachers are performing to eradicate the problems of supervision and supporting the supervisors in performing supervisory responsibilities. It was concluded that head teachers are taking a keen interest to achieve the students learning outcomes, educational objectives, ensuring the school environment clean and green, motivate students and teachers, allocating budget to achieve the improve the overall school environment, developing cooperation and communication with the community to improve the ratio of student's attendance and to achieve the universal primary education targets effectively. 


\section{RECOMMENDATIONS}

After the findings and conclusions, the researcher recommends the following recommendations, which were:

1. The Supervisors should assess the process of learning and teaching. The supervisors should focus to examine the overall school environment including physical, administrative and organizational activities of the schools.

2. The supervisors should prove themselves as role models for teachers and Heads of schools to behave them as a supporter, facilitator, consultant, and mentor to gain their support for effective results.

3. Elementary school head teachers should participate in the training sessions to improve the professional skills and approaches for the achievement of the educational aims and objectives and implement the policies of the government to raise the quality of education.

4. The government must ensure the provisions of physical and learning resources to achieve the learning outcomes, improve the child-friendly and healthy environment of the school and decrease the teaching-learning and supervisory problems.

\section{REFERENCES}

Institute Ahmad, I., Said, H., Khan, F., Yassin, M. A. M., Tahir, L. M., Bukhari, S. K. U. S., \& Ali, A. (2013). Barriers to Effective school inspection in Pakistan and Way Forward. World Applied Sciences Journal, 24(6), 814-821.

Ahmad, I., Rauf, M., Rashid, A., ur Rehman, S., \& Salam, M. (2013). Analysis of the problems of the primary education system in Pakistan: Critical review of the literature. Academic Research International, 4(2), 324.

Ahmad, I. (2014). Critical Analysis of the Problems of Education in Pakistan: Possible Solutions. International Journal of Evaluation and Research in Education, 3(2), 7984.

Adu, E. O., Akinloye, G. M., \& Olaoye, O. F. (2014). Internal and external school supervision: Issues, challenges and wayforward. International Journal of Educational Sciences, 7(2), 269-278.

Ali, M. A. (1998). Supervision for teacher development: A proposal for Pakistan. Unesco, International Institute for Educational Planning.

Al-Nazer, M., \& Mohammad, G. H. A. (2013). Supervising practices of education supervisors and their relationship with the attitudes of high basic stage teachers towards the profession in the Capital Amman Governorate from their point of view. Middle East University Amman, Jordan. International Journal of Humanities and Social Science, 3(2).

Behlol, M. G., Yousuf, M. I., Parveen, Q., \& Kayani, M. M. (2011). Concept of Supervision and Supervisory Practices at Primary Level in Pakistan. International Education Studies, 4(4), 28-35.

Carron, G., \& De Grauwe, A. (1997). Current issues in supervision: A literature review. Paris: 
International Institute for Educational Planning.

Creaner, M. (2013). Getting the Best Out of Supervision in Counselling \& Psychotherapy: A Guide for the Supervisee. Sage.

Dutta, R. K., Islam, M. S., \& Kabir, M. A. (2013). Haema to logical and biochemical profiles of Gallus indigenous, exotic and hybrid chicken breeds (Gallus domesticus 1.) from Rajshahi, Bangladesh. Bangladesh Journal of Zoology, 41(2), 135-144.

Drysdale, L., Goode, H., \& Gurr, D. (2011). Sustaining school and leadership success in two Australian schools. In How school principals sustain success over time (pp. 15-37). Springer, Dordrecht.

Donkoh, E. K., \& Dwamena, E. O. (2014). Effects of educational supervision on professional development: perception of public basic school teachers at Winneba, Ghana. British Journal of Education, 2(6), 63-82.

Ekyaw, B. A. (2014a). The practices and challenges of instructional supervision in Asossa Zone primary schools. Unpublished doctoral thesis), Jimma University, Ethiopia.

Ekyaw, B. A. (2014b). The practices and challenges of instructional supervision in Asossa Zone primary schools. Unpublished doctoral thesis), Jimma University, Ethiopia.

Ellis, C. R. (2007). No Child Left Behind--A critical analysis. Curriculum \& Teaching Dialogue, 9.

Fong, M. L. (1994). Multicultural issues in supervision. ERIC Clearinghouse.

Govinda, R., \& Tapan, S. (1999). Quality education through school-based supervision and support: The case of GSS primary schools in Bangladesh. International Institute for Educational Plannin, UNESCO.

Hart, G. M. (1994). Strategies and methods of effective supervision. ERIC Clearinghouse.

Memduhoğlu, H. B., Aydin, I., Yilmaz, K., Güngör, S., \& Oğuz, E. (2007). The process of supervision in the Turkish educational system: Purpose, structure, operation. Asia Pacific Education Review, 8(1), 56-70.

Oye, O. O. (2009). Perceived influence of supervision of instruction on teachers' classroom performance in ijebu-north education zone of Ogun state. Unpublished Masters Dissertation, Department of the Educational Foundations University of Nigeria, Nsukka.

Razzaq, J. (2012). The management of educational change in Pakistani educational institutions (Doctoral dissertation, University of Glasgow).

Tesema, A. (2014a). The practices and challenges of school-based supervision in government secondary schools of Kamashi Zone of Benishangul Gumuz Regional State (Doctoral dissertation, Jimma University).

Tesema, A., \& Abeshu, G. (2014b). The practices and challenges of school-based supervision in government secondary schools of Kamashi Zone of Benishangul Gumuz Regional State (Doctoral dissertation).

Vazir, N., \& Hussain, N. (2008). Exploring current practices of supervisors in government primary schools in Karachi, Pakistan. Journal of educational research, 11(1).

Wilcox, B. (2000). Making school inspection visits more effective: The English experience. UNESCO, International for Educational Planning. 